\title{
Chapter 14 \\ What Explains Increasing Euroscepticism in Switzerland? A Longitudinal Analysis
}

\author{
Oriane Sarrasin, Theresa Kuhn, and Bram Lancee
}

\section{Switzerland and the European Union}

On paper everything — or almost everything — points toward Switzerland being part of the European Union (EU). Indeed, this small but wealthy nation is situated at the heart of continental Europe, speaks three languages ${ }^{1}$ of EU members (German, French and Italian) and shares strong economic ties with EU members. Nonetheless the EU has never won Swiss hearts, or at least enough of them. In 1992 the Swiss people voted against joining the European Economic Area (EEA) by a short majority $(50.3 \%)$ of the voters and a comfortable majority of 18 cantons (Trechsel 2007). The country was clearly divided: Most members of the political and economic elite were in favour to joining the EEA, leading to an endorsement of $67 \%$ in Parliament, while the populist right-wing Swiss People's Party (SVP) led the opposition. Among Swiss citizens, those with a tertiary education or with a high income tended to support the EEA (Kriesi et al. 1993). There were strong regional disparities too, with Pro-EEA voters to be found mostly among the Swiss French: all French-speaking cantons voted "yes" with approval rates up to $79 \%$, while almost all Germanspeaking cantons and Ticino rejected it (Trechsel 2007).

\footnotetext{
${ }^{1}$ The fourth national language—Rumantsch—is spoken in Switzerland only.

O. Sarrasin $(\triangle)$

Faculty of Social and Political Sciences, University of Lausanne, Lausanne, Switzerland e-mail: oriane.sarrasin@unil.ch

T. Kuhn

Department of Political Science, University of Amsterdam, Amsterdam, Netherlands e-mail: Theresa.kuhn@uva.nl

B. Lancee

Department of Sociology, University of Amsterdam, Amsterdam, Netherlands e-mail: B.Lancee@uva.nl 


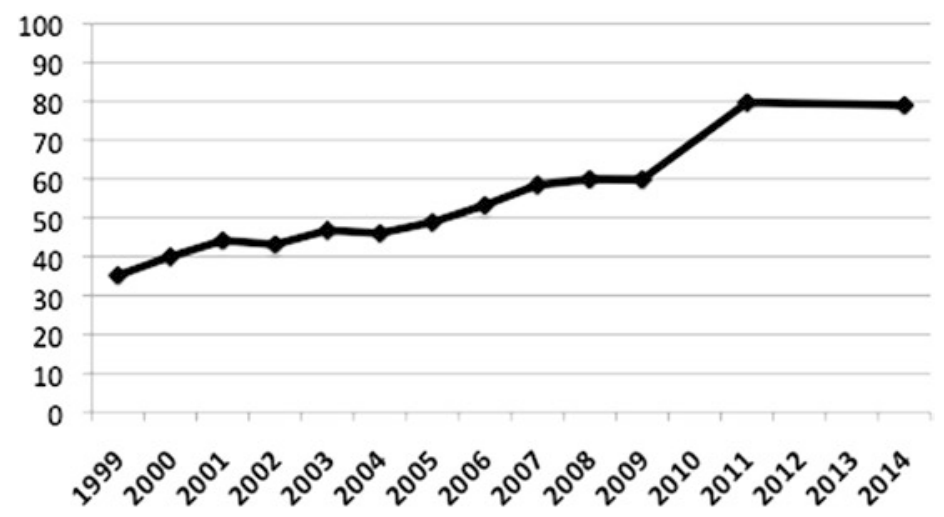

Fig. 14.1 Share of SHP respondents (Swiss citizens, aged minimum 15) who declared being unwilling to join the EU, from 1999 to 2014 (missing years are interpolated)

Reluctance to join the EU has consistently increased since then (see Fig. 14.1, based on the data used in the present chapter). In 2001, following an initiative launched by a pro-European movement (i.e., the European Movement Switzerland), Swiss people clearly voted against $(76.8 \%)$ opening the negotiations in sight of a potential adhesion to the EU. In 2016, a year after Iceland had withdrawn its application for membership and just days before the United Kingdom voted in favour of a "Brexit", Switzerland officially withdrew its application, which dated from 1992. This was the final step in a gradual decline of the interest of Swiss citizens to be part of the EU. Instead of a full membership to the EU, Switzerland has opted for an 'Alleingang' strategy: staying outside the EU, but maintaining strong economic ties with its members. This "middle way" solution takes the form of bilateral agreements that are very close to the EEA treaty. For instance, Switzerland is part of the Schengen Area, in which the free movement of people is guaranteed. However, even these bilateral agreements have been put into question after the Swiss people decided to limit the free movement of non-Swiss citizens to Switzerland through the so-called "mass immigration" initiative in February 2014 (Ambühl and Zürcher 2015).

While without any doubt there has been a strong decline in the share of Swiss citizens willing to join the EU since the 1990s, there is, to our knowledge, no longitudinal analysis of how changes within individuals affect their attitudes toward the EU. Indeed, while macro factors such as the 2008 economic crisis undoubtedly played a role in explaining the overall decline in support for joining the EU among Swiss citizens, individual life course changes may also explain why many of them withdrew their support for joining the EU at some point in their life. Literature on Euroscepticism in Switzerland (Christin and Trechsel 2002; Skinner 2013; Theiler 2004) has highlighted how, as they do elsewhere (Hooghe and Marks 2005; Hobolt and de Vries 2016), economic and political/cultural factors shape Swiss citizens' reactions to the EU. Extending this examination, we hypothesize that changes in these factors (e.g., a worsening personal financial situation, political ideologies 
leaning toward the right) may lead to decline in EU support among Swiss citizens that were initially pro-EU. We tested these hypotheses with data from the Swiss Household Panel (1999-2014).

\section{Predicting Unwillingness to Join EU among Swiss Citizens}

\section{Economic Factors}

Economic factors certainly play a role in influencing Swiss citizens' attitudes toward the EU. Switzerland is one the wealthiest countries of the European continent, with its gross domestic product growing every year despite the various financial crises that have hit its neighbours (Swiss State Secretariat for Economic Affairs-SECO, 2016a). For example, Switzerland has a very low unemployment rate (3.2\% in August 2016; SECO, 2016b). In such a prosperous context, Swiss citizens could fear that the country—and/or themselves directly—may lose by joining the EU (Schwok 2010). The fears may be particularly strong among the so-called "losers of globalization" (Kriesi et al. 2008). According to Gabel (1998), to understand who is winning or losing from EU membership, it is necessary to assess individuals' comparative advantage: Low skilled workers (e.g., with low educational attainment, low income or in low status occupations) from high-wage countries such as Switzerland face increased competition from workers from member states with lower wages, while highly skilled citizens of these countries are less affected by international competition. In a similar vein, it has been argued that the withdrawal of economic political borders resulting from EU membership benefits foremost to those who are mobile and connected (e.g., who have transnational ties or networks; Kuhn 2011). These "winners of globalization" possess the resources to cope with their country opening its borders. On the contrary, those depending more on local dynamics may fear that too much is at stake if their country joins the EU.

In line with this argument, European citizens who are worried for their personal as well as the national financial situations (Gabel 1998; Hooghe and Marks 2005) were found to report higher levels of Euroscepticism. Similar results were found in the case of European citizens with a lower income (Lubbers and Scheepers 2007). In addition, European citizens with fewer transnational ties (e.g., who were less likely to have lived abroad or to have socialised with non-nationals) were also found to be more Eurosceptic (Kuhn 2011). In Switzerland, the willingness to join the EEA in 1992 was found to be stronger among Swiss citizens with high income and high educational attainment (Kriesi et al. 1993). Ten years later, Christin and Trechsel (2002) found that Swiss citizens' level of concern about the economy in Switzerland was one of the central factors predicting their reluctance to join the EU. Based on this evidence, we hypothesize that low skilled Swiss citizens (e.g., in low status occupations or with low educational attainment) are less likely to support joining the EU (H1). In addition, Swiss citizens who perceive their personal financial situation as difficult are more likely to be reluctant to join the EU (H2a). 
Extending this reasoning, we expect a worsening personal financial situation to be accompanied with more negative attitudes toward the EU (H2b).

\section{Political and Cultural Factors}

The bulk of research on Euroscepticism has highlighted that cultural and political factors play a crucial role in predicting individuals' attitudes toward the EU. Indeed, public opinion toward the EU is driven by more than purely rational and utilitarian considerations (see for instance McLaren 2002). Among the numerous political and cultural factors that have been shown to shape individuals' attitudes toward the EU, ${ }^{2}$ we focus here on some political ideologies and attitudes that are likely to play a prominent role in the Swiss opposition to the EU.

A first political factor that is expected to drive Swiss citizens' attitudes toward the EU is their political orientation. Most studies on the relationship between political left-right ideology and EU attitudes have provided empirical support for the so-called "horseshoe model": Europeans at the left and right fringes of the political spectrum are more Eurosceptic than voters of mainstream parties (Aspinwall 2002; De Vries and Edwards 2009). While voters on left end are critical of the neo-liberal nature of European economic integration, right-wing Eurosceptics are motivated by the fear that European integration undermines the cultural integrity of their nation (Van Elsas et al. 2016).

By way of contrast the Swiss EU-opposition has been mostly led by right-wing parties, especially the radical right and populist Swiss People's Party (Schweizerische Volkspartei-SVP; Mazzoleni 2016). Constantly on the rise from the 1980s to the early 2010s, the SVP is now the strongest party in Switzerland with more than a quarter of the seats at the Federal Assembly (Swiss Parliament 2016). To a lesser extent, the center-right party Freisinnig-Demokratische Partei (FDP) also opposes EU membership but is generally open to bilateral agreements with the EU (Skinner 2013). Contrary to other non-EU members (e.g., Norway), Swiss left-wing political parties tend to support an adhesion to the EU (Skinner 2013). Because of this rightleft divide when it comes to the EU among Swiss political parties, we expect Swiss citizens who subscribe to right-wing ideologies to oppose joining the EU to a greater

\footnotetext{
${ }^{2}$ Political and cultural factors other than those under consideration here (e.g., national identity, and fears of losing specific Swiss institutions such as neutrality or direct democracy) were shown to shape Swiss citizens' reluctance to join the EU (see Schwok 2010). Since no question about these specific points was asked in the SHP, they cannot be investigated in the present chapter. Regarding national identity, people who exclusively identify with their own country are more likely to be Eurosceptic than individuals who identify (also) as European (Citrin and Sides 2004; Hooghe and Marks 2004) In Switzerland, attachment to the nation is especially high in the German-speaking region (Green et al. 2011), where the strongest opposition to the EU is also found (Theiler 2004). Attitudes toward joining the EU are also more negative in the Italian-speaking region than in the French-speaking region. For this reason and since there is no measure of national identity in the SHP, we account for the linguistic region in our analyses.
} 
extent than Swiss citizens with left-wing political ideologies (H3a). In addition, having one's political orientation moving toward the right should be accompanied with more negative attitudes toward the EU (H3b).

Related to claims at the heart of SVP argumentation, a second political factor that likely plays a role is people's subjective feeling of lack of political influence. Like many other populist parties, SVP often argues that the voice of Swiss citizens are not sufficiently heard by the government and authorities, and that citizens should decide for themselves. Consequently, Switzerland should bypass international regulations. An example is the on-going campaign on "Swiss self-determination", an SVP initiative to make Swiss law prime over international laws and rules (SVP 2016). We thus expect that Swiss citizens who feel that they have no political influence are more likely to oppose joining the EU (H4a). Furthermore, increasing feelings of lack of political influence should result in a stronger reluctance to join the $\mathrm{EU}(\mathrm{H} 4 \mathrm{~b})$.

\section{Data}

The nature of our hypotheses_-predicting differences between individuals and within individuals, requires panel data. We therefore analyzed data from the Swiss Household Panel (1999-2014), the only longitudinal survey in Switzerland that contains questions regarding Swiss citizens' willingness to join the EU. We restricted our sample to Swiss citizens, aged at least $15(M=46.26, S D=17.61)$. Missing data for the dependent variable were omitted (with the exception of years where the EU item was not included, see below). This resulted in 75,565 observations provided by 14,436 respondents ( 5.23 observations on average per respondent). There were slightly more female respondents $(55.17 \%)$. Reflecting the linguistic division of Switzerland, the majority of respondents $(70.60 \%)$ lived in the German-speaking region (French-speaking region: 25.77\%, Italian-speaking region: $3.63 \%$ ).

\section{Measures}

Dependent variable Swiss citizens' reluctance to join the EU was measured with the following item: "Are you in favour of Switzerland joining the European Union or are you in favour of Switzerland staying outside of the European Union?" Possible answers were 1 = "in favour of joining the EU", 2 = "Neither" or 3 = "In favour of staying outside the EU." Because we study unwillingness to join the EU, we created a dichotomous variable: 1 = staying outside the EU vs. $0=$ else. Note that this item was not included in the survey in 2010, 2012 and 2013. For these years the missing value was imputed with the value of the previous year. Altogether, the 
share of respondents who favoured staying outside the EU increased from $35.2 \%$ in 1999 to $78.9 \% 3$ in 2014 (see Fig. 14.1).

Independent variables First, a set of variables was used to distinguish between the potential winners and losers of globalization. Skills (H1) were measured with respondents' occupational prestige and educational attainment. Occupational prestige was measured with the Cambridge Social Interaction and Stratification Scale (CAMSIS), a continuous instrument that relies on social interactions to estimate individuals' social status (for the Swiss version, see Bergman et al. 2002). Possible CAMSIS scores range from 0 to 100 (in the present data: from 9.50 to 97.15 , $M=56.08, S D=14.32$ ). Education was measured as the highest level of education; we reduced a 17-category scale to a 6-category one (see Bergman et al. 2009): Primary education $(15.05 \%)$, secondary without high school diploma (Matura, in Switzerland; $1.31 \%)$, secondary with Matura (10.53\%), secondary vocational $(43.98 \%)$, tertiary vocational $(16.82 \%)$ and university $(12.32 \%)$.

Respondents' perception of their financial situation (H2) was evaluated with the following item: "Overall how satisfied are you with the financial situation of your household". Possible answers range from $0=$ not at all satisfied to $10=$ completely satisfied $(M=7.52, S D=1.94)$. We focused on the household's financial situation instead of one's individual finical position because a considerable share of respondents did not work (e.g., housewives, students, minors). Furthermore, finances are most often organised at the household level, rather than at the individual level. In the case of respondents who reported being in employment, we also took into account their perceived risk of unemployment in the next 12 months (from $0=$ no risk at all to $10=$ a real risk; $M=1.86, S D=2.37$ ). When it comes to political factors, respondents were first asked where they placed themselves, from $0=$ left to $10=$ right $(\mathrm{H} 3$; $M=4.83, S D=2.12)$. Their perceived political influence $(\mathrm{H} 4)$ was measured with scale ranging from $0=$ no influence to $10=$ a very strong influence $(M=3.87$, $S D=2.55)$.

Control variables Age and gender $(1=$ male $)$ were included as younger generations (Down and Wilson 2013) and men (Nelsen and Guth 2000) have been shown to be more supportive of European integration. We also considered whether participants had another citizenship ( $1=$ bi- or tri-national; $10.92 \%)$, since those with a transnational background tend to be less Eurosceptic (Kuhn 2011). Respondents' labour force status was tapped with the following categorical scale: working full time (reference; $35.95 \%$ ), working part time (23.18\%), studying $(11.80 \%)$, being a home carer $(9.10 \%)$, being retired $(16.96 \%)$, being unemployed $(1.00 \%)$, and other occupation $(2.00 \%)$. We then controlled for respondents' interest in politics, from $0=$ not at all interested to $10=$ very interested $(M=5.69, S D=2.71)$. Finally, because there are known marked differences in support for joining the EU across the Swiss linguistic regions, we considered where respondents lived: We created two dichotomous variables (Swiss German versus and Swiss Italian versus other, with Swiss French as a reference category).

${ }^{3}$ Please note that all analyses were conducted on unweighted data. 


\section{Results}

Because of the dichotomous nature of the dependent variable we estimated logit regressions; odd ratios are displayed in the tables. We first estimated random effects (RE) models. RE models use both between-person and within-person variance to estimate coefficients. In a second step, we analyse changes within individuals by estimating fixed-effects (FE) models. As FE models only estimate within-individual changes, one cannot include variables for which there were no changes (such as gender or the linguistic region). Finally, because some variables affect only those working (i.e., occupational prestige and probability of losing one's job), we estimated additional RE and FE models including only employed individuals.

\section{Differences between Respondents}

Results are displayed in Table 14.1, left column. Confirming our hypothesis (H1), Swiss citizens with higher educational attainment (with a Matura or a tertiary degree compared to those with primary education only) were less likely to be Eurosceptic. Note that respondents with secondary education (without Matura) and secondary vocational education did not differ from those with primary education only. In addition and as hypothesized $(\mathrm{H} 2 \mathrm{a})$, respondents who reported not being satisfied with the state of their household finances were less likely to support joining the EU. When it comes to political and cultural factors, as expected (H3a), self-reported right-wing ideologies were related to a higher probably to reject the EU. Contrary to our expectations (H4a), the more respondents felt that they had a political influence, the more they opposed the EU.

In line with previous literature on Euroscepticism, male and older respondents reported being less willing to join the EU. Students and retired people were more likely to oppose EU membership than citizens working full time, while home carers were less likely. The less interest in politics they expressed, the more respondents were likely to oppose joining the EU. Finally, respondents living in the German- and Italian-speaking regions were more likely to oppose joining the EU than those living in the French-speaking region.

Results of additional analyses performed with respondents in (full or part time) employment are displayed in the right column of Table 14.1. As hypothesized (H1), a higher socsial status was related to a lower probability to oppose joining the EU. Though in the expected direction, the probability to be unemployed within the next 12 months was only marginally significantly related to attitudes toward the EU (H3a). 
Table 14.1 Logisitic RE regression predicting unwillingness to join the EU (whole sample and sample restricted to respondents in employment), odd ratios

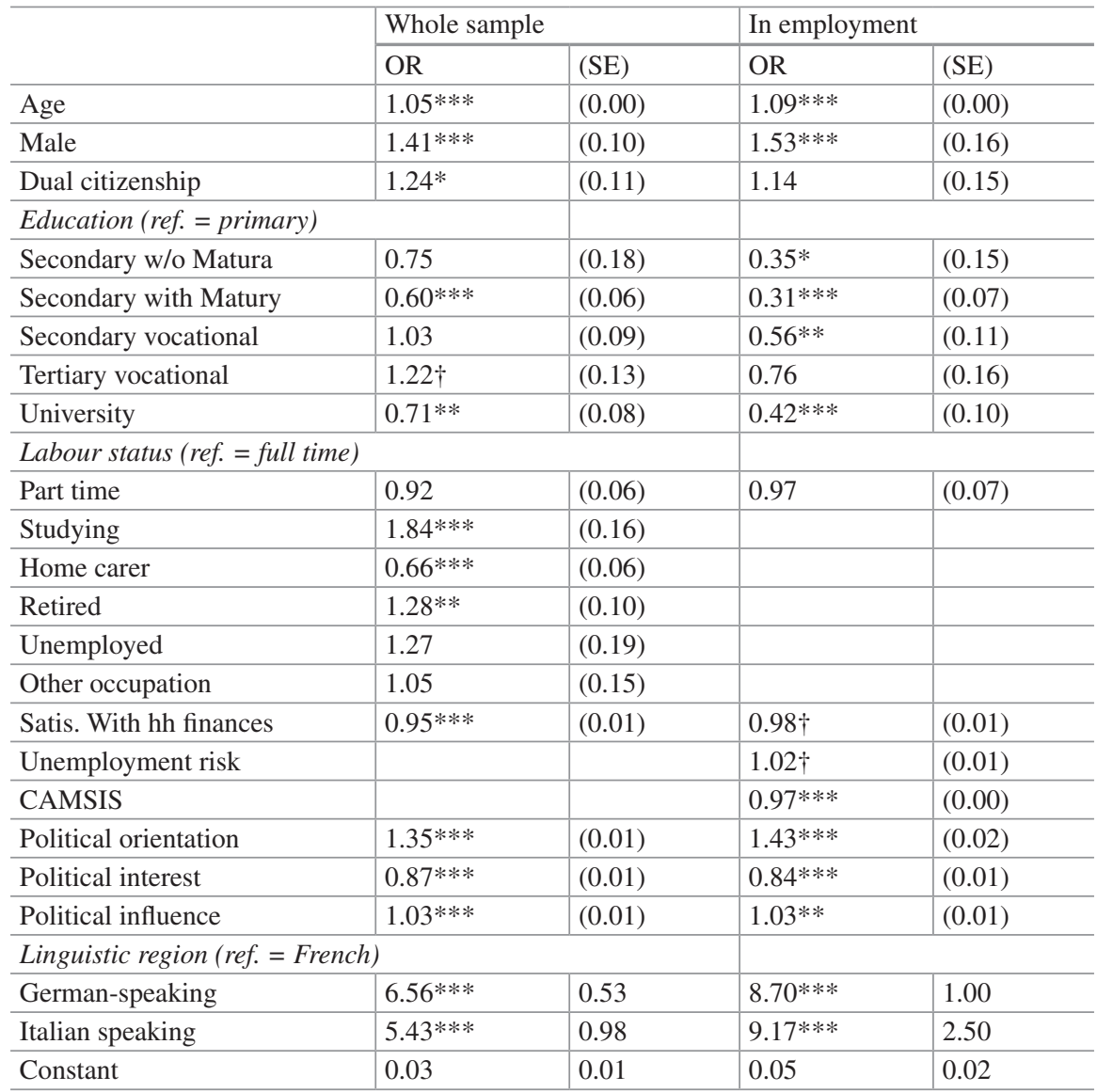

*** $p<.001 ; * * p<.01$; two-sided tests

Source: SHP 1999-2014

\section{Changes within Respondents}

Results are displayed in Table 14.2, left column. Only a few within-individual changes yielded a significant impact on attitudes toward the EU. Contrary to our expectations, changes in economic factors were not accompanied with a change in attitudes toward the EU (H2b). When it comes to political factors, increasingly right-wing political attitudes $(\mathrm{H} 2 \mathrm{~b})$ were significantly related to a higher probability to oppose joining the EU (H3b). By way of contrast, changes in feelings of political influence had no impact $(\mathrm{H} 4 \mathrm{~b})$. When it comes to the control variables, reaching 
Table 14.2 Logisitic FE regression predicting unwillingness to join the EU (whole sample and sample restricted to respondents in employment), odd ratios

\begin{tabular}{l|l|l|l|l}
\hline & \multicolumn{2}{l}{ Whole sample } & \multicolumn{2}{l}{ In employment } \\
\cline { 2 - 5 } & OR & (SE) & OR & $($ SE) \\
\hline Age & $1.38^{* * *}$ & 0.01 & $1.41^{* * *}$ & 0.01 \\
\hline Education (ref. = primary) & \multicolumn{1}{l}{} & \multicolumn{2}{l}{} \\
\hline Secondary w/o Matura & 1.18 & 0.49 & 0.46 & 0.45 \\
\hline Secondary with Matury & 0.95 & 0.13 & $4.56 \dagger$ & 3.96 \\
\hline Secondary vocational & 0.84 & 0.13 & 2.18 & 1.78 \\
\hline Tertiary vocational & 0.88 & 0.17 & 3.10 & 2.56 \\
\hline University & 1.09 & 0.24 & 3.40 & 2.97 \\
\hline Labour status (ref. $=$ full time) & & & & \\
\hline Part time & 0.95 & 0.08 & 1.03 & 0.11 \\
\hline Studying & 0.95 & 0.12 & & \\
\hline Home carer & 0.91 & 0.12 & & \\
\hline Retired & $1.35^{*}$ & 0.16 & & \\
\hline Unemployed & 1.00 & 0.19 & & 0.02 \\
\hline Other occupation & 0.98 & 0.19 & & 0.01 \\
\hline Satis. with hh finances & 1.02 & 0.01 & 1.02 & 0.01 \\
\hline Unemployment risk & & & 0.99 & 0.02 \\
\hline CAMSIS & & & 0.99 & 0.02 \\
\hline Political orientation & $1.10^{* * *}$ & 0.01 & $1.10^{* *}$ & 0.01 \\
\hline Political interest & $0.95^{* * *}$ & 0.01 & $0.94^{* * *}$ & \\
\hline Political influence & 0.99 & 0.01 & 1.01 & \\
\hline
\end{tabular}

*** $p<001 ; * * p<01 ; * p<05 ; \dagger p<10$; two-sided tests

Source: SHP 1999-2014

retirement and a decreasing interest in politics were related to more negative attitudes toward the EU. Finally, additional analyses performed on respondents in employment (Table 14.2, right column) show that, contrary to our expectations ( $\mathrm{H} 1 \mathrm{~b}$ and $\mathrm{H} 2 \mathrm{~b}$ ), neither a lower social status nor an increased probability to be unemployed are related to a higher probability to oppose joining the EU.

\section{Conclusion}

The analyses we performed on the SHP data (1999-2014) provided results in line with previous literature on Euroscepticism: Both economic and political factors matter in shaping Swiss citizens' attitudes toward the EU. On the one side, the socalled losers of globalization - that is, those who are less likely to benefit from an adhesion to the EU (e.g., individuals with low skills)—were found to be more likely 
to oppose joining the EU. On the other side, individuals who report right-wing political ideologies reported a stronger opposition than those with left-wing ideologies.

Analyzing changes within individuals - which is rarely done when investigating attitudes toward the EU-sheds further light on the respective weight of economic and political factors. Moving toward the right side of the political spectrum was related to an increased probability to oppose joining the EU. This illustrates the relationship, in Switzerland, between radical right or populist ideologies and the willingness to shut (or remain close) Switzerland's boundaries. In contrast, changes in individual's life course were largely unrelated to changes in attitudes toward the EU. While economic factors explain variation between individual's attitudes towards joining the EU, transitions within individuals could not be related to changes in attitudes. This suggests that the bulk of the overall decline in joining the EU among Swiss citizens may be due to macro-factors (e.g., economic crises). It might also be that joining the EU is not seen as impacting individuals' life, hence the lack of effect from changes in personal financial situation. Overall, this is in line with the argument that apparent divide between the losers and winners of globalization may be more cultural than utilitarian. For instance, when it comes to attitudes toward immigration in Switzerland, it has been found that most of the differences between lowly and highly educated are in place before young people start education (Lancee and Sarrasin 2015). Thus, the impact of education-often attributed to the acquisition of skills-is likely to be explained by the social origins of individuals. A similar mechanism may be at play with regard to attitudes toward the EU.

To sum up, it seems highly unlikely that Swiss citizens will decide to join the EU at any time in the future. Furthermore, the more they will move to the right of the political spectrum, the more they will move away from the EU. For this reason, future research on the topic should concentrate on attitudes toward the bilateral agreements, such as investigated in the SHP in 2012 and 2015. This is all the more relevant since Swiss citizens' decisions-such as limiting immigration to Switzerland-may call into question these agreements.

\section{References}

Ambühl, M., \& Zürcher, S. (2015). Immigration and Swiss-EU free movement of persons: Question of a safeguard clause. Swiss Political Science Review, 21, 76-98.

Aspinwall, M. (2002). Preferring Europe ideology and national preferences on European integration. European Union Politics, 3, 81-111.

Bergman, M. M., Lambert, P., Prandy, K., \& Joye, D. (2002). Theorization, construction and validation of a social stratification scale: Cambridge social interaction and stratification scale (CAMSIS) for Switzerland. Swiss Review of Sociology, 28, 7-25.

Bergman, M., Hupka, S., Joyce, D., \& Meier, T. (2009). Recodification de la formation dans les enquêtes. Basel: Basel University.

Christin, T., \& Trechsel, A. H. (2002). Joining the EU? Explaining public opinion in Switzerland. European Union Politics, 3, 415-443. 
Citrin, J., \& Sides, J. (2004). More than nationals: How identity choice matters in the new Europe. In R. Herrmann, M. Brewer, \& T. Risse (Eds.), Transnational isdentities: Becoming European in the $E U$ (pp. 161-185). Lanham: Rowman \& Littlefield.

De Vries, C., \& Edwards, E. (2009). Taking Europe to its extremes: Extremist parties and public Euroscepticism. Party Politics, 15, 5-28.

Down, I., \& Wilson, C. J. (2013). A rising generation of Europeans? Life-cycle and cohort effects on support for 'Europe'. European Journal of Political Research, 52, 431-456.

Gabel, M. (1998). Interests and integration: Market liberalization, public opinion, and European Union. Ann Arbor: University of Michigan Press.

Green, E. G. T., Sarrasin, O., Fasel, N., \& Staerklé, C. (2011). Nationalism and patriotism as predictors of immigration attitudes in Switzerland: A municipality-level analysis. Swiss Political Science Review, 17, 369-393.

Hobolt, S. B., \& de Vries, C. E. (2016). Public support for European integration. Annual Review of Political Science, 19, 413-432.

Hooghe, L., \& Marks, G. (2004). Does identity or economic rationality drive public opinion on European integration? PS-Political Science \& Politics, 37, 415-420.

Hooghe, L., \& Marks, G. (2005). Calculation, community, and cues: Public opinion on European integration. European Union Politics, 6, 421-445.

Kriesi, H., Longchamp, C., Passy, F., \& Sciarini, P. (1993). Analyse der eidgenössischen Abstimmung vom 6. Dezember 1992. VOX Nr (p. 47). GfS and DSP: Adliswil.

Kriesi, H., et al. (2008). West European politics in the age of globalization. Cambridge: Cambridge University Press.

Kuhn, T. (2011). Individual transnationalism, globalisation and euroscepticism: An empirical test of Deutsch's transactionalist theory. European Journal of Political Research, 50, 811-837.

Lancee, B., \& Sarrasin, O. (2015). Educated preferences or selection effects? A longitudinal analysis of the impact of educational attainment on attitudes toward immigrants. European Sociological Review, 31, 490-501.

Lubbers, M., \& Scheepers, P. (2007). Explanations of political euro-scepticism at the individual, regional and national levels. European Societies, 9, 643-669.

Mazzoleni, O. (2016). Between opposition and government: The Swiss People's party. In F. Decker, B. Henningsen, \& K. Jakobsen (Eds.), Rechtspopulismus und Rechstextremismus in Europa: Die Herausforderung der Zivilgesellschaft durch alte Ideologien und neue Medien (pp. 110-118). Baden-Baden: Nosmos Verlag.

McLaren, L. (2002). Public support for the European Union: Cost/benefit analysis or perceived cultural threat. Journal of Politics, 64, 551-566.

Nelsen, B., \& Guth, B. (2000). Exploring the gender gap: Women, men and public attitudes toward European integration. European Union Politics, 1, 267-291.

Schwok, R. (2010). Suisse - Union européenne : L'adhésion impossible? Lausanne: Presses Polytechniques et Universitaires Romandes,. Collection Le Savoir Suisse.

Skinner, M. S. (2013). Different varieties of Euroscepticism? Conceptualizing and explaining Euroscepticism in western European non-member states. Journal of Common Market Studies, $51,122-139$.

State Secretariat for Economic Affairs. (2016a). GDP quarterly estimates. Retrieved from https:// www.seco.admin.ch/seco/en/home/wirtschaftslage---wirtschaftspolitik/Wirtschaftslage/bipquartalsschaetzungen-.html

State Secretariat for Economic Affairs. (2016b). Arbeitslosenquote nach Kantonen [unemployment rate per canton]. Retrieved from https://www.amstat.ch/v2/?lang=de

Swiss Parliament. (2016). Council members. Retrieved from https://www.parlament.ch/en/ ratsmitglieder?k=*.

Swiss People Party. (2016). Volksinitiative „Schweizer Recht statt fremde Richter (Selbstbestimmungsinitiative). Retrieved from http://www.svp.ch/kampagnen/uebersicht/ selbstbestimmungsinitiative/um-was-geht-es/ 
Theiler, T. (2004). The origins of Euroscepticism in German-speaking Switzerland. European Journal of Political Research, 43, 635-656.

Trechsel, A. (2007). Direct democracy and European integration: A limited obstacle. In C. Church (Ed.), Switzerland and the European Union: A close, contradictory and misunderstood relationship (pp. 36-51). London: Routledge.

Van Elsas, E. J., Hakhverdian, A., \& van der Brug, W. (2016). United against a common foe? The nature and origins of Euroscepticism among left-wing and right-wing citizens. West European Politics, advance online publication.

Open Access This chapter is licensed under the terms of the Creative Commons Attribution 4.0 International License (http://creativecommons.org/licenses/by/4.0/), which permits use, sharing, adaptation, distribution and reproduction in any medium or format, as long as you give appropriate credit to the original author(s) and the source, provide a link to the Creative Commons license and indicate if changes were made.

The images or other third party material in this chapter are included in the chapter's Creative Commons license, unless indicated otherwise in a credit line to the material. If material is not included in the chapter's Creative Commons license and your intended use is not permitted by statutory regulation or exceeds the permitted use, you will need to obtain permission directly from the copyright holder. 